\title{
Occurrence of Phytophthora Species in Commercial Nursery Production
}

Corina Junker, Patrick Goff, Stefan Wagner, and Sabine Werres, Federal Biological Research Center for Agriculture and Forestry (JKI), Institute for Plant Protection in Horticulture and Forestry, 38104 Braunschweig, Germany

Accepted for publication 14 March 2016. Published 11 April 2016.

\section{ABSTRACT}

Junker, C., Goff, P., Wagner, S., and Werres, S. 2016. Occurrence of Phytophthora in commercial nursery production. Plant Health Prog. 17:64-75.

Two commercial woody ornamental nurseries were sampled for the presence of Phytophthora species over a period of three years between 2011 and 2014. The samples were taken every two months at different propagation (greenhouses, plastic tunnels) and cultivation (container stands) areas as well as from nearby pathways and from a water recycling system with a slow sand filter. Furthermore, different materials like soil, substrates, residues, wind-carried leaves, water and sediment were sampled. In total, 12 known Phytophthora species could be detected. Further, three isolates did not match any of the known species.
Phytophthora ramorum, $P$. gonapodyides, and $P$. plurivora were the species with the highest detection rates. Phytophthora ramorum could be detected during all seasons of the year. In total, the puddles on the pathways had the highest percentage of positive detections. Residues, wind-carried leaves and water and sediment from the water runoffs were also good places for Phytophthora survival. In both nurseries, the plant samples showed very low infection rates. Ideas for surveys and management are discussed.

\section{INTRODUCTION}

Multiple surveys and epidemiological studies have shown that nurseries are an important source for the global spread of the fungus-like microorganisms of the genus Phytophthora (Bienapfl and Balci 2014; Duff 1994; Hardy and Sivasithamparam 1988; Hulvey et al. 2010; Prospero et al. 2013; Rytkonen et al. 2012; Schlenzig et al. 2015; Themann et al. 2002b; Vercauteren et al. 2013; Warfield et al. 2008; Werres et al. 2007). Detailed genetic studies demonstrate the introduction and spread of Phytophthora species, for example, P. ramorum (Eyre and Garbelotto 2015; Goss et al. 2009; Goss et al. 2011; Van Poucke et al. 2012) and P. plurivora (Schoebel et al. 2014). The spread of these pathogens to natural habitats can result in severe ecological damage. This is well demonstrated for P. ramorum (Chastagner et al. 2011; Eyre and Garbelotto 2015; Prospero et al. 2013; Shishkoff 2011; Van Poucke et al. 2012; Webber et al. 2010). Therefore, the eradication of Phytophthora is recommended for nurseries.

Most surveys and studies are based on the sampling of symptomatic plants (see references above); some also include other samples, like water from different sources used for irrigation (Bush et al. 2003; Ghimire et al. 2011; Hong et al. 2011; Hong et al. 2008; Loyd et al. 2011; Loyd et al. 2014; Themann et al. 2002b; Tjosvold et al. 2008). There is little knowledge, however, about the occurrence and survival of Phytophthora during the different steps of commercial plant production. This information is necessary for the development of good management strategies for Phytophthora in nurseries.

Therefore, the present study focused on sampling at different stages of propagation and cultivation of plants along with

Corresponding author: Sabine Werres. Email: sabine.werres@julius-kuehn.de.

doi:10.1094/PHP-RS-15-0045

(C) 2016 The American Phytopathological Society sampling different materials like substrates, residues, windcarried leaves, and water and/or sediment. The results should help nursery managers to get a better understanding of "survival places" of Phytophthora species in their nursery and to develop better sanitary procedures. The results may also help to develop good protocols for sampling in nurseries for Phytophthora. These protocols can be used for surveys and monitoring.

\section{NURSERIES, SAMPLES, SAMPLING DATES, AND DIAGNOSTIC METHODS}

Two commercial nurseries were chosen for the study. Nursery 1 had a production area of about 19 ha, and nursery 2 of about 50 ha. Both nurseries produced mainly woody ornamentals including Rhododendron spp. Our study concentrated on Rhododendron because they are one of the most important host plants for Phytophthora ramorum in Europe. Both nurseries propagated Rhododendron themselves. Nursery 2 commissioned the rooting by a third nursery until the first year of the project and rooted the cuttings themselves in the following years. Nursery 2 had a water recycling system and used a slow sand filter to clean the surplus water.

Between August 2011 and May 2014, a total of 498 samples were taken. Sampling was done every two months except in January 2013. In addition, 18 samples were taken in November and December 2011 from the third nursery where the cuttings from nursery 2 were rooted. The sampling focused mainly on selected areas used for the propagation and cultivation (Fig. 1, Table 1) and on different sampling materials (Fig. 2, Table 2). For the soil, substrate, residues, water, sediment, and rootball samples, the Rhododendron leaf test was used (Themann and Werres 2000; Themann et al. 2002a). Living cultures of Phytophthora isolates were obtained from the baits and from symptomatic plant samples by direct isolation on carrot piece agar without selective amendments according to Werres et al. (2001). Bait leaves and samples from the symptomatic plant samples 

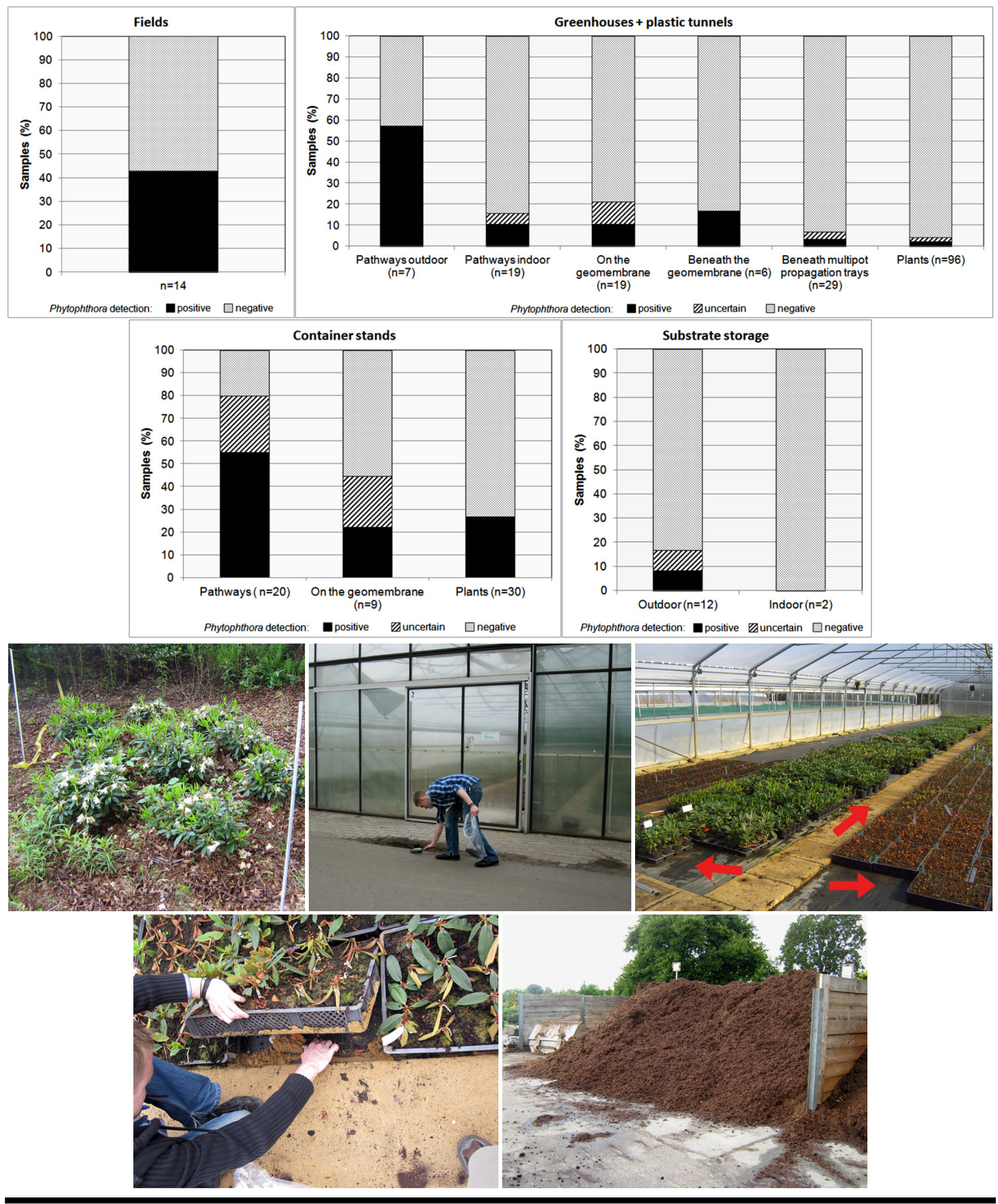

FIGURE 1A

Detection of Phytophthora by sampling areas in nursery 1. Upper two rows from left to right: Detection of Phytophthora in the fields; in greenhouses and plastic tunnels; on container stands; and in an outdoor place for substrate storage. Lower two rows from left to right: Sampling in the field; on the pathway in front of a greenhouse; sampling places (red arrows) in a greenhouse covered with film; sampling beneath multipot propagation trays; and at an outdoor storage place for potting media. 

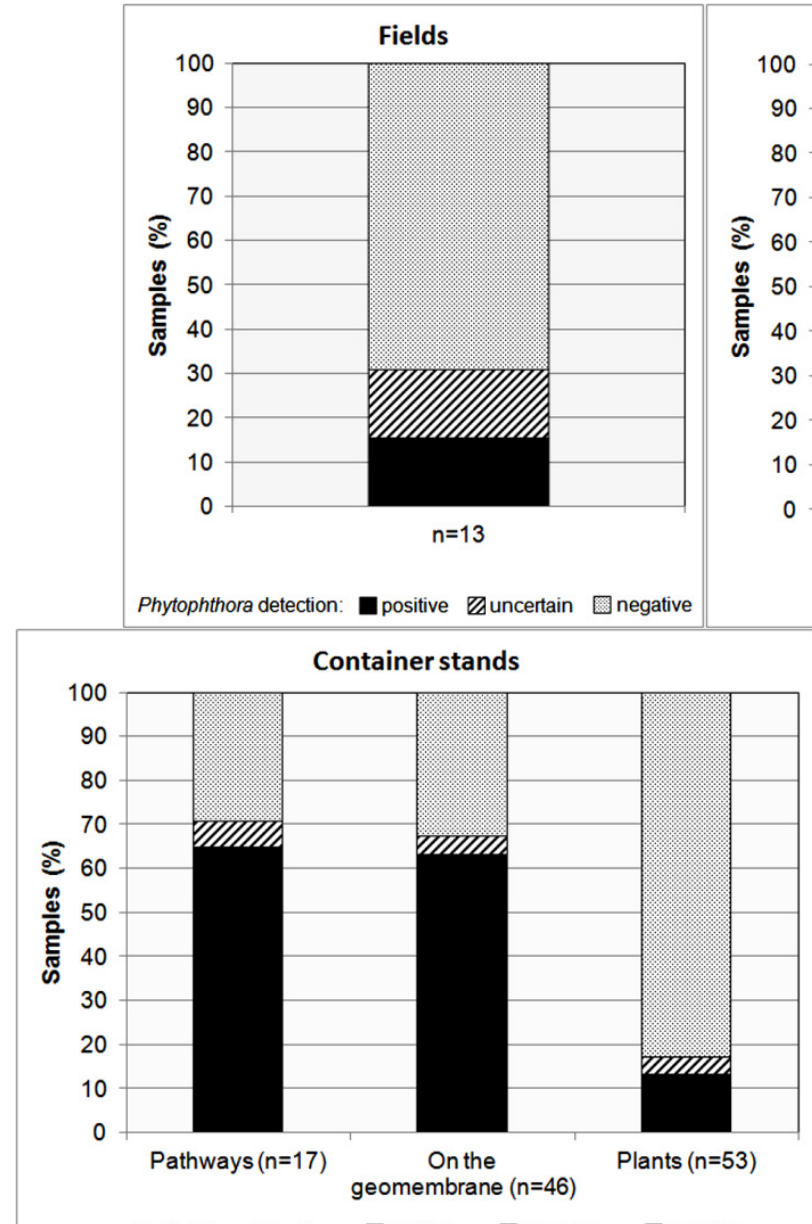

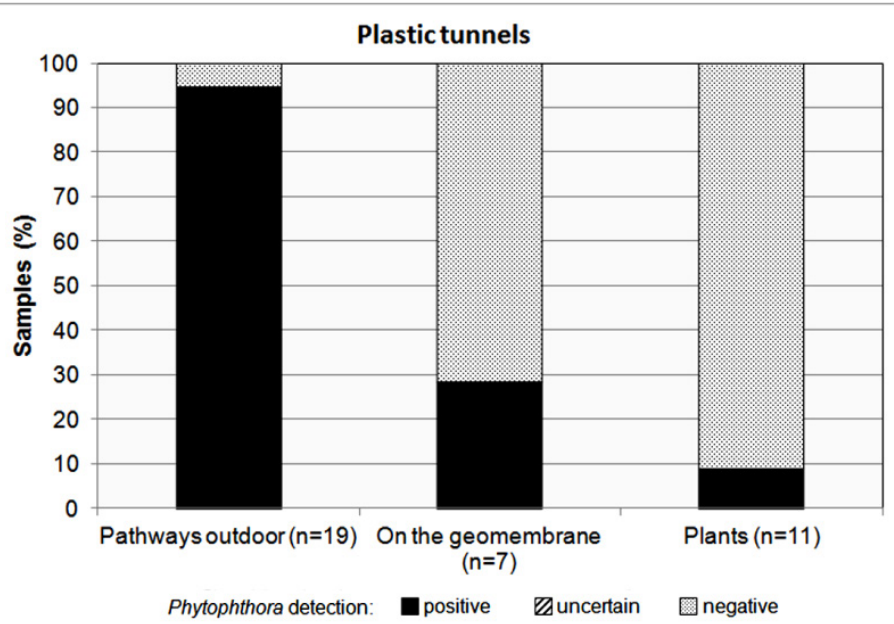

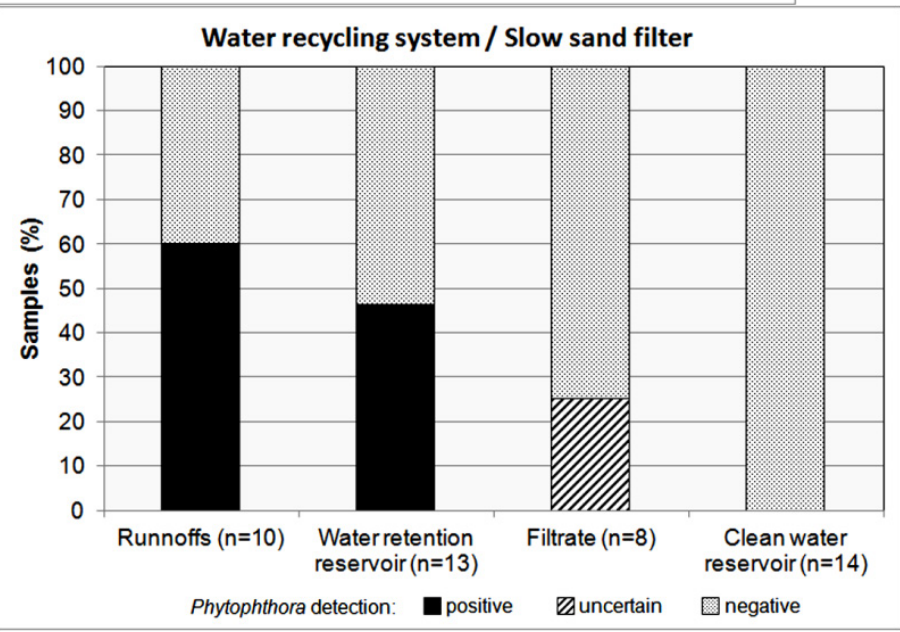
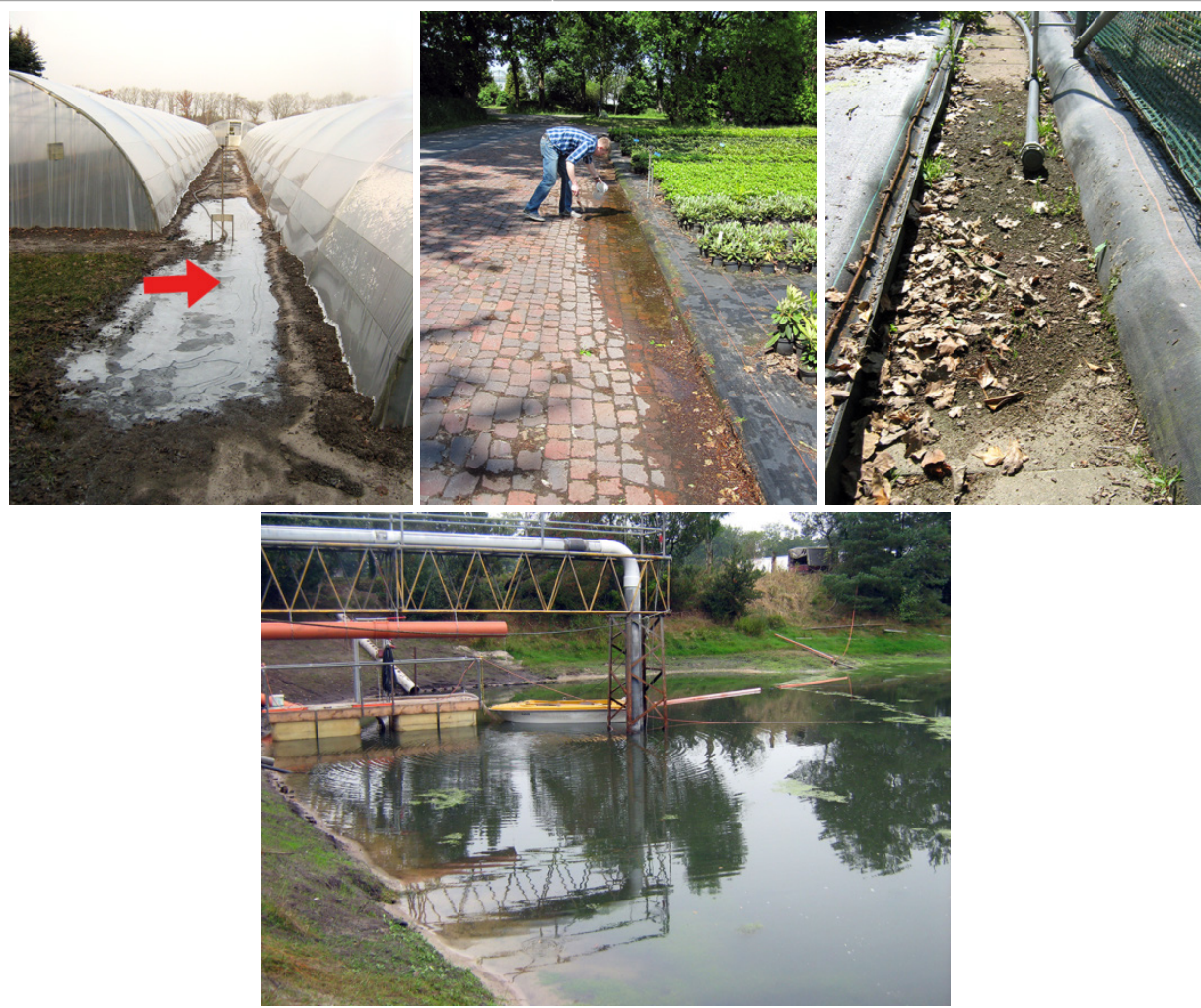

\section{FIGURE 1B}

Detection of Phytophthora by sampling areas in nursery 2. Upper two rows from left to right: Detection of Phytophthora in the fields; in plastic tunnels; on container stands; and in the water recycling system with slow sand filter. Lower two rows from left to right: Sampling on a pathway between plastic tunnels (red arrow); on a pathway close to a container stand; in a runoff; and in a water retention reservoir for recycling water. 


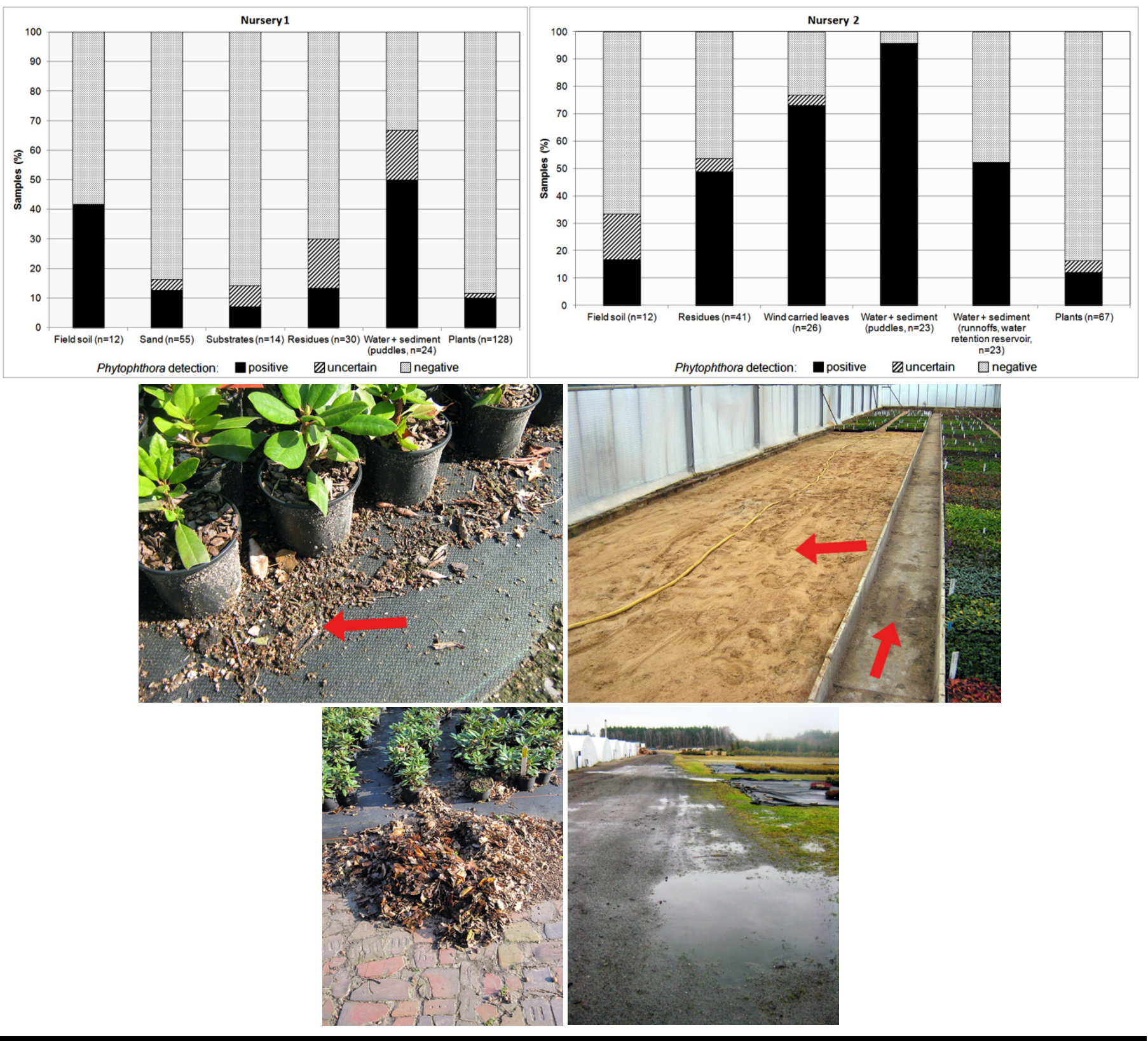

\section{FIGURE 2}

Detection of Phytophthora from different sampling materials. Upper row from left to right: Detection of Phytophthora in nursery 1 and 2. Lower two rows from left to right: Organic residues on a container stand; sand layer and sand residues on a pathway in a greenhouse; wind-carried leaves on a pathway close to a container stand; and puddle on a pathway.

were double checked with a genus-specific primer for Phytophthora spp. according to Schena et al. (2008). Interpretation of the results was as follows: Direct isolation that resulted in a living Phytophthora culture was called "Phytophthora positive" regardless of whether the PCR was also positive. Positive results that were obtained only by PCR with the genus-specific primer but without successful isolation was judged as "uncertain." When no method gave positive results, the sample was said to be "Phytophthora negative." The living cultures were identified by morphology and sequence analysis (ITS 1/4) (White et al. 1990). Interpretation of the sequence analysis was according to Grunwald et al. (2011). The ITS had to correspond $>99 \%$ with the data available in the NCBI GenBank database (http://www.ncbi.nlm.nih.gov/genbank), Phytophthora-ID (Grunwaldt et al. 2011), and Q-Bank (http://www.q-bank.eu). If the sequence matched $<99 \%$, the species was addressed as "complex."

\section{WEATHER DATA}

Air temperature and precipitation were measured continuously from August 2011 until May 2014. All data were measured by the nearest official meteorological station relevant to each nursery.

In Germany, the climate is characterized by moderate to cool summers and by mild winters. Rain falls year round with a maximum in summer. During the three years of the study, temperatures ranged from $-19.1^{\circ} \mathrm{C}$ (nursery 1 ) and $-15.3^{\circ} \mathrm{C}$ (nursery 2) to $34.8^{\circ} \mathrm{C}$ (nursery 1 ) and $35.0^{\circ} \mathrm{C}$ (nursery 2) (Fig. 3, Table 3). The winter of 2012-2013 was relatively cold with 109 days of frost $\left(<0^{\circ} \mathrm{C}\right.$, October to April) in nursery 1 and 84 in nursery 2. In 2012 and 2013, nursery 1 had more days with 
TABLE 1

Detection of Phytophthora species in different propagation and cultivation sections.

\begin{tabular}{|c|c|c|c|c|c|c|c|c|c|}
\hline \multirow{2}{*}{ Phytophthora species } & \multicolumn{9}{|c|}{ Sampling areas } \\
\hline & \multicolumn{2}{|c|}{ Fields } & $\begin{array}{c}\begin{array}{c}\text { Green- } \\
\text { houses }^{a} \\
1 \\
n=108\end{array}\end{array}$ & \multicolumn{2}{|c|}{ Plastic tunnels } & \multicolumn{2}{|c|}{$\begin{array}{l}\text { Container } \\
\text { stands }\end{array}$} & $\begin{array}{c}\text { Outdoor } \\
\text { substrate } \\
\text { storage }^{b} \\
1 \\
n=12\end{array}$ & $\begin{array}{c}\text { Water } \\
\text { recycling } \\
\text { system } \\
2 \\
n=49\end{array}$ \\
\hline P. cactorum & $\mathbf{x}$ & & & & & & & & \\
\hline $\begin{array}{l}\text { P. citricola } \\
\text { complex } P \text {. cryptogea / P. drechsleri }\end{array}$ & & & & & & $\mathbf{X}$ & $\mathbf{x}$ & & \\
\hline complex P. humicola / P. inundata & & & $\mathbf{x}$ & $\mathbf{x}$ & & $\mathbf{x}$ & & & \\
\hline P. lacustris & & & & & & & $\mathbf{x}$ & & $\mathbf{x}$ \\
\hline P. megasperma & & & & $\mathbf{x}$ & & & & & \\
\hline P. plurivora & $\mathbf{x}$ & $\mathbf{x}$ & $\mathbf{x}$ & $\mathbf{x}$ & $\mathbf{X}$ & $\mathbf{x}$ & $\mathbf{x}$ & & $\mathbf{x}$ \\
\hline P. ramorum & $\mathbf{X}$ & $\mathbf{x}$ & $\mathbf{x}$ & $\mathbf{x}$ & $\mathbf{X}$ & $\mathbf{x}$ & $\mathbf{x}$ & $\mathbf{X}$ & $\mathbf{x}$ \\
\hline P. rosacearum, complex & & & & & $\mathbf{x}$ & & $\mathbf{x}$ & & \\
\hline
\end{tabular}

$\mathrm{X}=$ detection of the Phytophthora species. Blank = no detection of the Phytophthora species.

${ }^{a}$ No greenhouses in nursery 2.

${ }^{\mathrm{b}}$ No water recycling system in nursery 1 .

${ }^{c}$ No outdoor substrate storage in nursery 2.

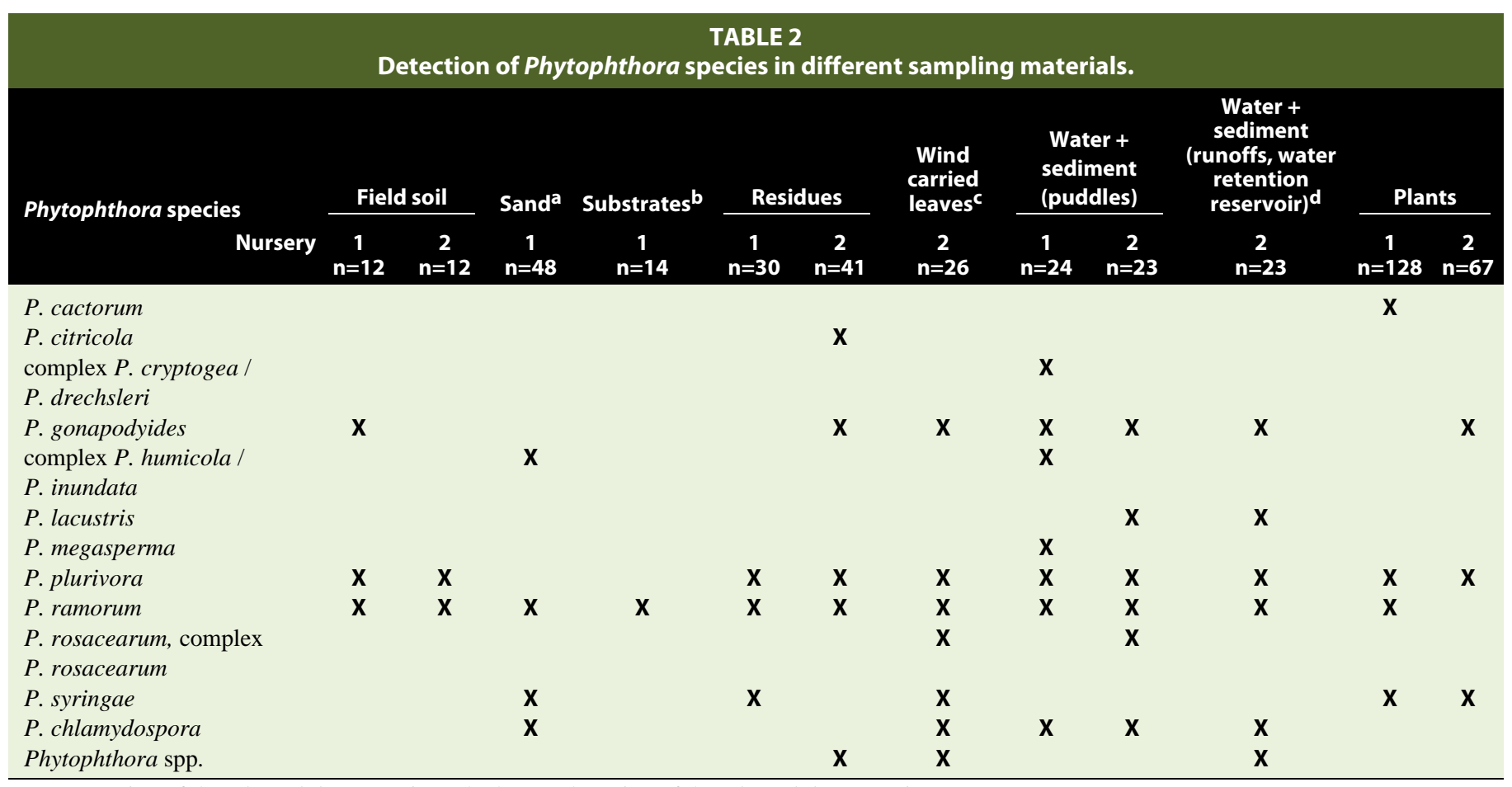

$\mathrm{X}=$ Detection of the Phytophthora species. Blank = no detection of the Phytophthora species.

${ }^{a}$ Only one sand sample in nursery 2.

${ }^{b}$ No outdoor substrate storage in nursery 2 .

${ }^{\mathrm{c}}$ No wind carried leaves in nursery 1.

${ }^{\mathrm{d}}$ No water recycling system in nursery 1 . 


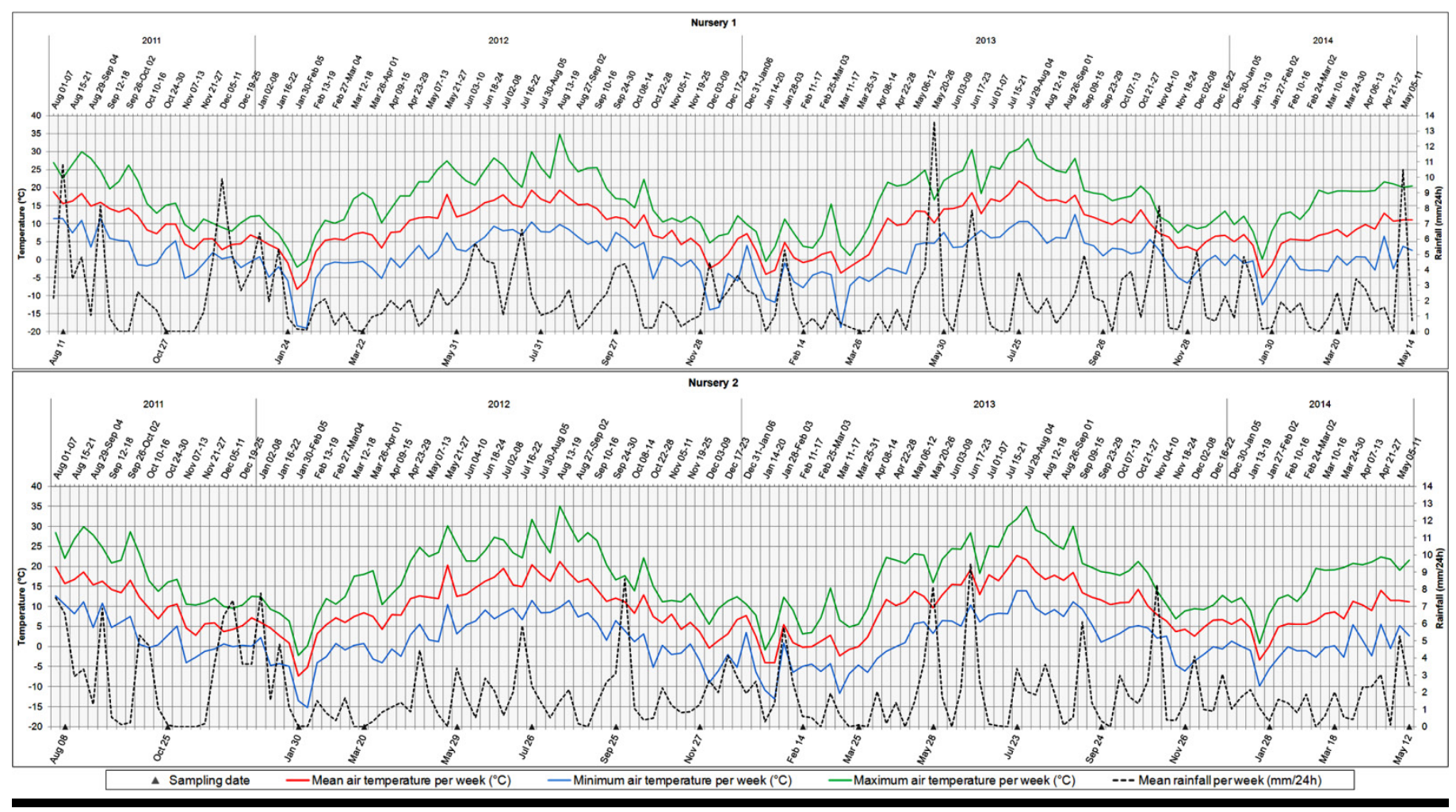

FIGURE 3

Meteorological data for the sampling period (August 2011 to May 2014).

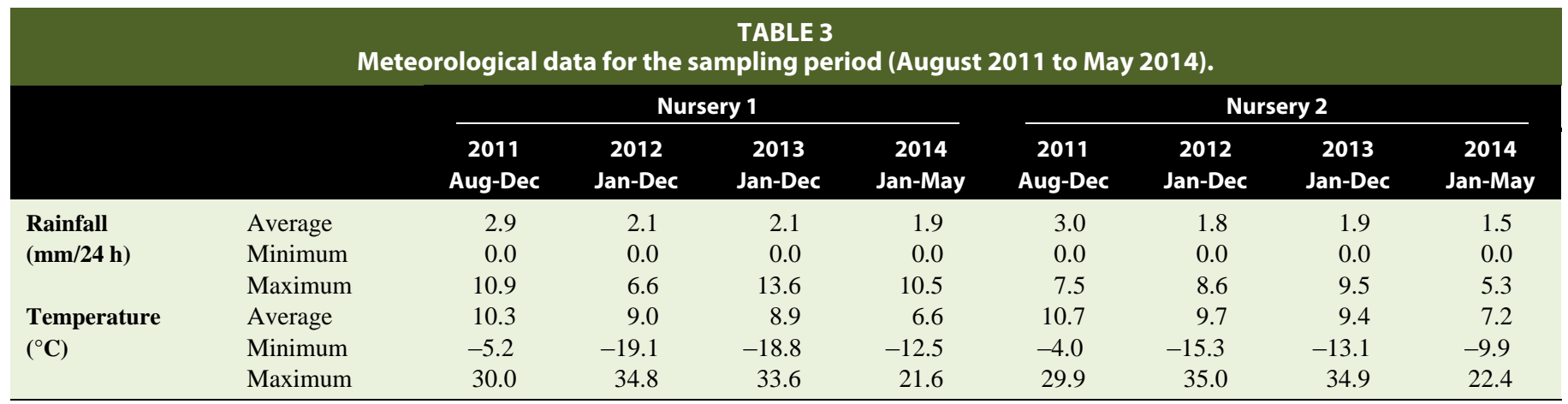

temperatures $>25^{\circ}$ (47 in May to September 2012, 62 in May to September 2013) than nursery 2 (31 in May to September 2012, 27 in June to September 2013). For the years 2011 to 2014, the annual average rainfall in Germany ranged between 722 and 779 $\mathrm{mm} /$ year. Nursery 1 was located in an area with more rainfall (annual averages 2011 to 2014: 754 to $821 \mathrm{~mm} / \mathrm{year}$ ) than nursery 2 (annual averages 2001 to 2014: 622 to $704 \mathrm{~mm} /$ year).

\section{PHYTOPHTHORA SPECIES DETECTED}

In nursery 2 more than twice as many samples tested positive for Phytophthora (37.4\%) than in nursery 1 (15.9\%) (Fig. 4). The number of uncertain detections was low: $5.4 \%$ in nursery $1,4.5 \%$ in nursery 2 . In both nurseries the majority of samples testing positive contained only a single Phytophthora species; only a low number of samples yielded two species (Fig. 5). Only in nursery 2 $7.2 \%$ of the samples positive for Phytophthora contained three Phytophthora species. In nursery 3 where samples were taken only in November and December 2011 two of the 18 samples were positive, and three were uncertain.

In total 12 Phytophthora species were detected (Fig. 6). Further three isolates did not match any of the known species. The dominant species were $P$. gonapodyides, $P$. plurivora and $P$. ramorum, but the range of species and the frequency of occurrence varied with the nursery: For example, $P$. gonapodyides was primarily detected in nursery $2(59.4 \%$ of the positive samples) while $P$. ramorum occurred in $50 \%$ of the positive samples in nursery 1 but only in approximately one third of the samples from nursery 2 . The number of "uncertain" detection was higher in nursery 1 than in nursery 2 . It was interesting to see that in the samples with more than one Phytophthora species nearly always $P$. gonapodyides was the accompanying species. $P$. ramorum was mainly found together with $P$. gonapodyides and/or P. plurivora (data not shown). In nursery 3 the three positive samples were contaminated with $P$. ramorum. This finding was the decisive element in the manager's decision from nursery 2 to cancel the subcontract for rooting at nursery 3 .

\section{DETECTION OF PHYTOPHTHORA BY YEAR AND SEASON}

Phytophthora was detected in all three years of the study (Fig. 7). In nursery 2, the number of positive samples seemed to decrease until February 2013, than increased until the end of the study. 


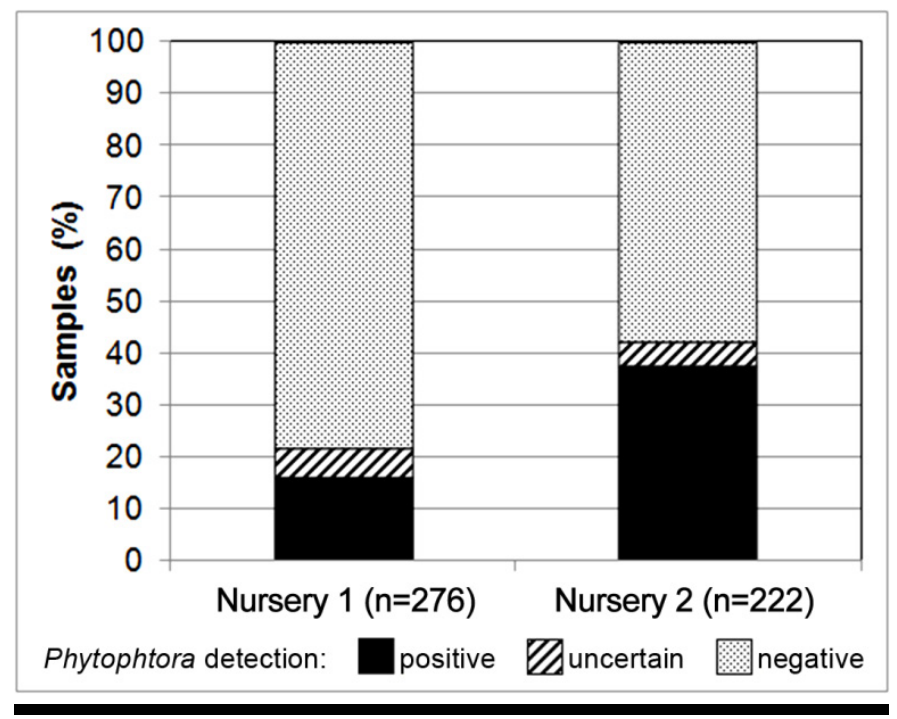

FIGURE 4

Samples with Phytophthora.

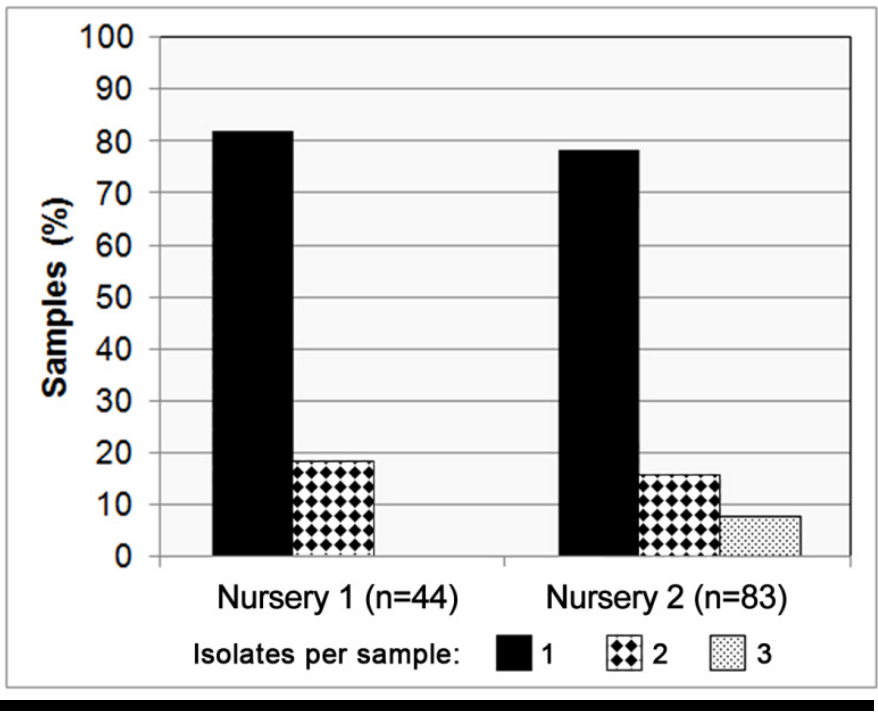

FIGURE 5

Number of Phytophthora species detected per sample. " $n$ " = number of samples tested positive for Phytophthora.

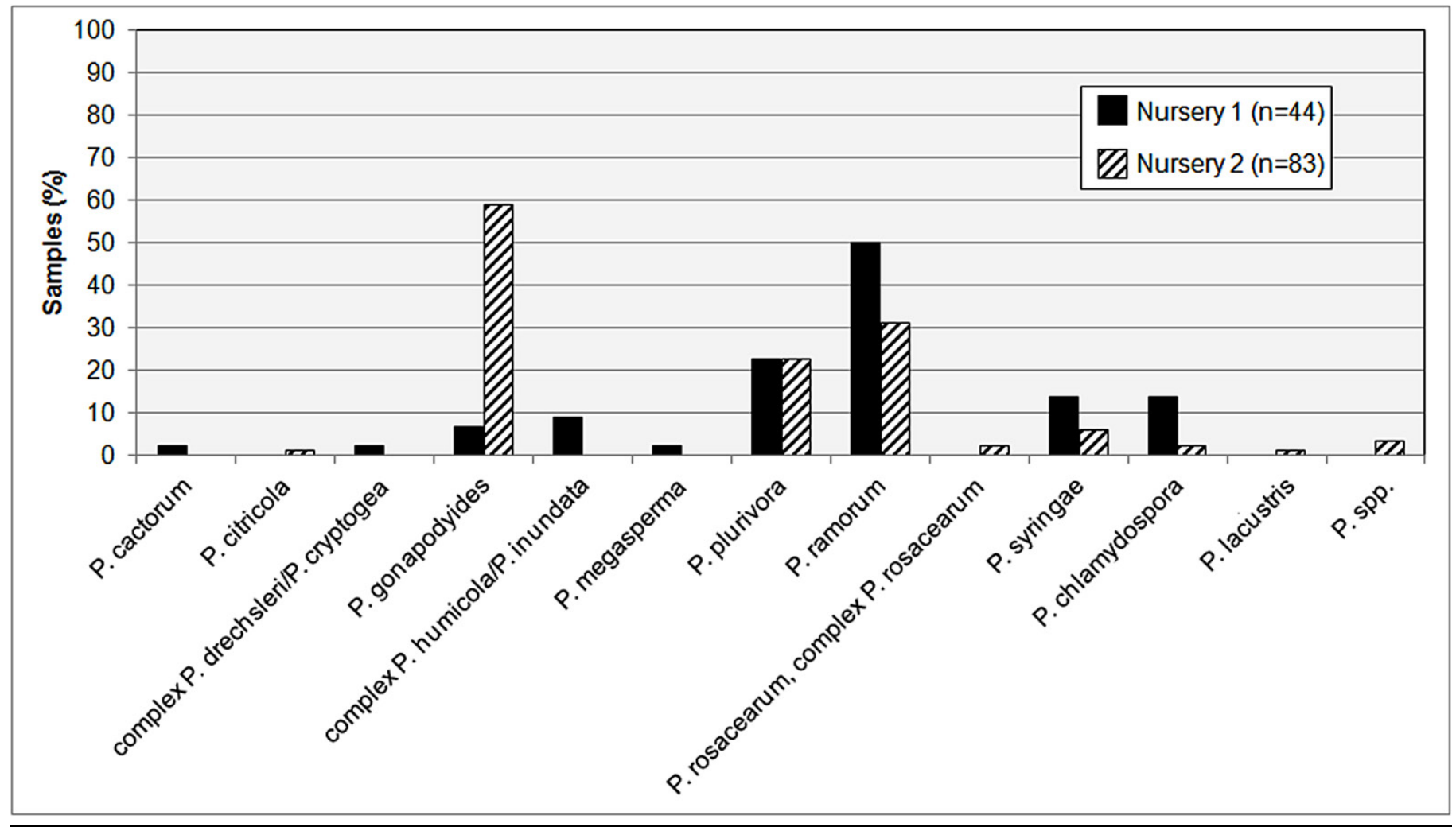

\section{FIGURE 6}

Range of Phytophthora species detected. " $\mathrm{n}$ " = number of samples tested positive for Phytophthora.

Within the two nurseries Phytophthora could be detected during every season (Fig. 7). Even when the samples were frozen during winter, i.e. like the water in puddles or the soil, live cultures of Phytophthora could be obtained (data not shown).

Some Phytophthora species were only detected once, for example $P$. cactorum, $P$. citricola and $P$. drechsleri/P. cryptogea, while others, like $P$. ramorum, $P$. plurivora and $P$. gonapodyides were detected during nearly all seasons of the year (Table 4) but with varying rates in the two nurseries: While in nursery 2 the three latter Phytophthora species were present at nearly each sampling date, in nursery $1 P$. plurivora could only be detected between October 2011 and July 2012 and in May 2014; $P$. gonapodyides was found only in May 2012 and 2014 and in September 2013 (data not shown). There was no correlation between Phytophthora detection and temperatures or rainfall.

\section{DETECTION OF PHYTOPHTHORA IN THE PROPAGATION/CULTIVATION AREA AND IN THE WATER RECYCLING SYSTEM}

Both nurseries cultivated the majority of their Rhododendron as containerized plants, and valuable old plants (mother plants) were maintained as field-grown stock. Nursery 1 rooted the 

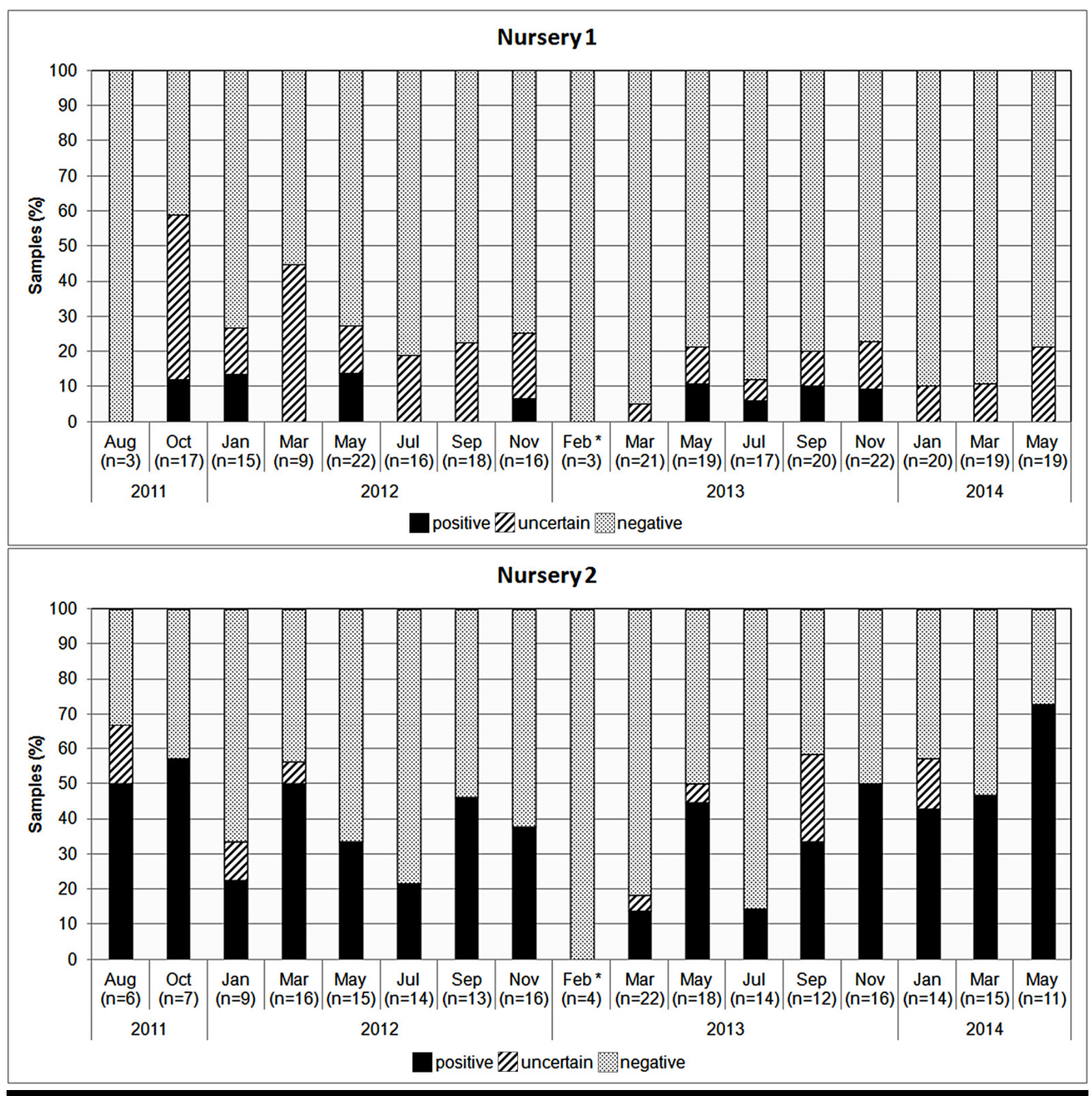

\section{FIGURE 7}

Detection of Phytophthora by year and the month. *In February 2013 sampling was not possible; the nursery managers sent samples.

Rhododendron in greenhouses or in greenhouses covered with film and hardened the young plants in multipropagation trays in plastic tunnels, mainly on a sand layer but in some plastic tunnels also on geomembranes with sand layers beneath. The 1-year-old Rhododendron were than cultivated on container stands. Nursery 2 used only plastic tunnels for rooting and hardening and container stands for further cultivation. The plastic tunnels had stands covered with a geomembrane and only a single pathway in the middle covered with stones. These pathways were kept very clean so that no good samples could be taken. Sampling beneath the geomembrane was only possible in nursery 1 on an old container stand where the membrane was removed to reconstruct the stand.
In both nurseries, Phytophthora could be detected at all sampling areas (Figs. 1A and 1B). In the covered sections, the highest percentage of positive samples $(57.1 \%$ in nursery 1 and $94.7 \%$ in nursery 2) came from the outdoor pathways close to the entrances of the greenhouses and plastic tunnels. In the greenhouses and plastic tunnels, Phytophthora could be detected on the indoor pathways (only sampling in nursery 1) and on the stands for the multipropagation trays (Figs. 1A and 1B). The sampling in nursery 1 showed that the pathogens were present on the indoor stands no matter whether the sublayer under the multipropagation trays was a geomembrane or sand. The situation on the container stands was similar; the highest percentages of positive samples $(55.0 \%$ in nursery $1,64.7 \%$ in nursery 2 ,) were 


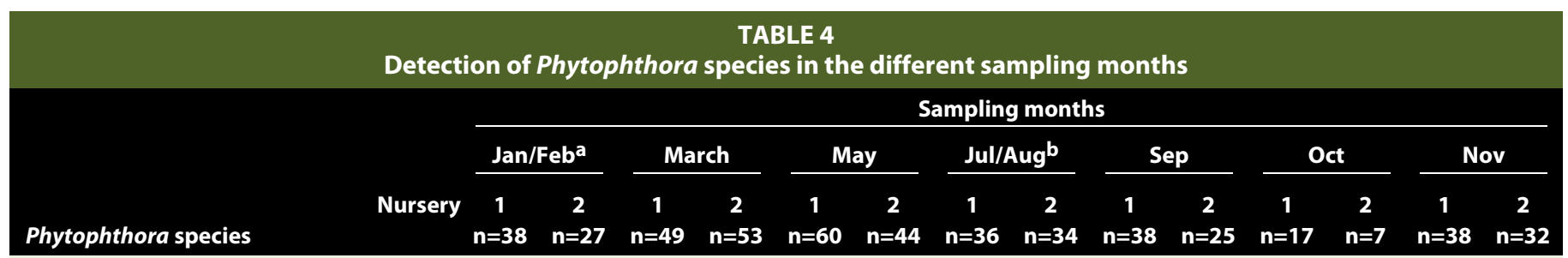

\section{$P$. cactorum}

$P$. citricola

complex P. cryptogea / P. drechsleri

$P$. gonapodyides

complex $P$. humicola / P. inundata

$P$. lacustris

P. megasperma

P. plurivora

$P$. ramorum

$P$. rosacearum, complex $P$. rosacearum

P. syringae

$P$. chlamydospora

$P$. spp.
$\mathbf{X}$

$\mathbf{X}$

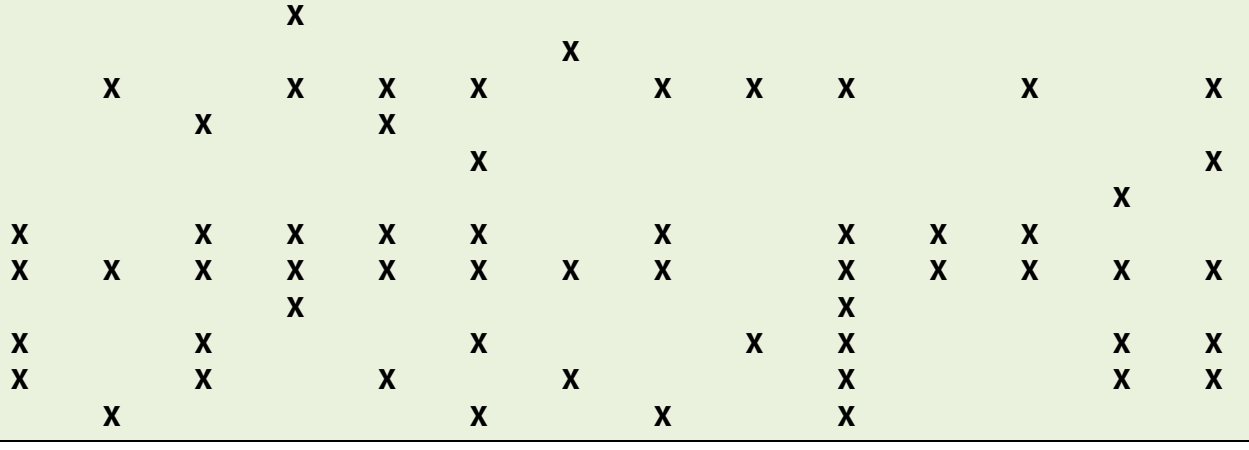

$\mathrm{X}=$ detection of the Phytophthora species; blank = no detection of the Phytophthora species.

a 2013 sampling was in February instead of January.

b 2011 sampling was in August instead of July.

on the pathways nearby (Fig. 1A and 1B). On the container stands of nursery 2 the detection rate was nearly similar $(63.0 \%)$ but much lower in nursery $1(22.2 \%)$. In both nurseries, the detection rates of Phytophthora in the plant samples increased from the propagation/hardening section (the increase can be seen in Fig. 1A for nursery 1 and in Fig. 1B for nursery 2) to the container stands (Fig.1). In addition, an indoor and an outdoor storage place for substrates could be sampled in nursery 1 ; in $8.3 \%$ of the samples stored open air Phytophthora could be detected (Fig. 1A). The sampling of the water recycling system with slow sand filtration in nursery 2 showed the highest percentage of positive samples $(60 \%)$ in the runoffs followed by the water retention reservoir (48.2\%) (Fig. 1B). The $25 \%$ of filtrate samples with uncertain Phytophthora detection originated from sampling dates soon after the filter had been switched on after a longer period of switchoff. In the samples from the clean water reservoir, no detection of the pathogens was possible.

In both nurseries, the widest range of Phytophthora species could be detected in the samples from the container stands (Table 1). A wide range of species was also present in the samples from the plastic tunnels and in the water recycling system of nursery 2. Phytophthora ramorum was present in all areas, similarly with $P$. plurivora that was not detected only at the sections for substrate storage in nursery 1. Phytophthora gonapodyides was present in samples from the fields (only in nursery 1), from plastic tunnels and container stands (both nurseries), and from the water recycling system in nursery 2 .

In nursery 1 , single samples were taken from beneath the geomembranes of an old container stand under construction. Out of the four samples taken, two were positive: one yielded $P$. chlamydospora and the other yielded $P$. chlamydospora and $P$. ramorum (data not shown).

\section{DETECTION OF PHYTOPHTHORA IN DIFFERENT SAMPLING MATERIALS}

Materials chosen for sampling were: (i) field soil from the mother plant sections (both nurseries); (ii) sand from the layers beneath the multiport propagation trays or beneath the geomembranes in the greenhouses and plastic tunnels (only in nursery 1); (iii) substrates from the indoor and outdoor storage section (mainly in nursery 1 , see section above); (iv) residues that usually were present on container stands between the containers or in the covered sections between the multipropagation trays or on the pathways (both nurseries); and (v) water and sediment from puddles on the pathways (both nurseries) and (vi) from the water recirculation system (nursery 2). In nursery 2, extra samples were taken from wind-carried oak leaves because many Quercus robur trees grew close to the production areas. Fallen oak leaves from nursery boarders were carried by wind to the container stands where they often accumulated at the edges of the container stands and mixed with other residues, soil, or sand.

Phytophthora could be detected in all sampled materials. The highest percentages (50.0\% in nursery $1,95.7 \%$ in nursery 2 ) came from the water and sediment samples taken from puddles on the outdoor pathways (Fig. 2). In nursery 1, the second highest contamination rate $(41.7 \%)$ was in the field soil. All other sampling materials in this nursery had detection rates below $15 \%$. In nursery 2 , the second highest detection rate was from the windcarried oak leaves $(73.1 \%)$ followed by the water and sediment samples from the runoffs and the water retention reservoir (52.2\%) and the residues (48.8\%). In both nurseries, the plant samples showed very low detection rates $(16.2 \%$ in nursery 1 , $11.9 \%$ in nursery 2 ).

In both nurseries, the widest range of Phytophthora species could be detected in the water and sediment samples from the puddles (Table 2). Multiple species of Phytophthora could also be detected in the water and sediment samples from the runoffs, from the retention reservoir, and in the wind-carried leaves from nursery 2. Phytophthora ramorum was present in all materials sampled except the plant samples of nursery 2 . This species was also present in rootball samples from asymptomatic Rhododendrons in nursery 1. Phytophthora plurivora could also be detected in nearly all materials including the rootballs of asymptomatic Rhododendron but not in the sand and the substrate samples. Phytophthora gonapodyides was mainly present in the water and sediment samples but also in the residues and in windcarried oak leaf samples of nursery 2 . Concerning the plant samples, only one rootball sample from nursery 2 showed contamination with $P$. gonapodyides (data not shown). 


\section{DISCUSSION AND RECOMMENDATIONS FOR NURSERY PRACTICE}

The numerous detections clearly show that Phytophthora species can survive in different areas and materials of commercial plant production. It is very obvious that contaminated pathways are the best inoculum source for the spread of these Phytophthora species throughout a nursery. Many nurseries have unpaved pathways. The bumpy pathways have puddles that offer Phytophthora excellent conditions for survival. Water runoffs and retention reservoirs are further good places for survival of the water-borne Phytophthora species (Ghimire et al. 2011; Hong et al. 2011; Parke et al. 2004; Themann et al. 2002b; Werres et al. 2007). On the container stands and on any kind of indoor stands, the residues seem to be the most important source for inoculum. Most of the residues contained plant debris from, for example, fallen leaves of the cultivated plants. It is well known that Phytophthora can survive for long periods in plant tissue (Linderman and Davis 2006; Rytkonen et al. 2013; Shishkoff 2007). It is not yet clear whether the wind-carried common oak leaves in nursery 2 were infected with the Phytophthora species isolated or whether the debris, soil, or sand mixed with these leaves in nursery 2 carried the isolates. Studies with oak species and Phytophthora gave varying results; susceptibility of Quercus robur varied with the Phytophthora species (Balci et al. 2008), from low susceptibility to $P$. ramorum (Denman et al. 2005) to no infection with $P$. ramorum (Rytkonen et al 2012). Varying susceptibility of other oak species to $P$. ramorum was also demonstrated by Widmer et al. (2010).

Plants did not seem to be the best subjects to sample for nursery surveys of Phytophthora. The high contamination rates in the samples from the pathways and residues close to the plant stands did not correspond with the detection rates of Phytophthora in the plant samples. The reason could be the application of fungicides specific for oomycetes. But there is the risk that the fungicides do not always kill Phytophthora so that plants remain asymptomatic for a long period. If asymptomatic plants will be surveyed, sampling from rootballs or the surrounding potting medium can help to detect latent infection (Parke 2007; Ufer et al. 2008; Vercauteren et al. 2013; Werres et al. 2007).

The results showed that under the climatic conditions in Western Europe, even in winter, survival of many Phytophthora species is possible in containerized plants and in other materials. Studies with $P$. ramorum indicate that low temperatures increase the inoculum levels (Tjosvold et al. 2008; Vercauteren et al. 2013). In our studies there was no clear correlation between temperature/rainfall and the detection rate of $P$. ramorum. It may be that the "artificial" situation of plant cultivation in a nursery has a greater influence on the inoculums level and/or quality. For example, high nitrogen fertilization can increase the susceptibility of Rhododendron towards Phytophthora especially if the cultivar is susceptible (Hoitink and Powell 1990; Hoitink et al. 1986; Hummel et al. 2013). Other factors can be water or osmotic stress (Blaker and MacDonald 1981; Roubtsova and Bostock 2009).

Contaminated material presents the highest risk for the spread of Phytophthora, but the risk for plant infection seems less clear. For example, to cause disease with contaminated irrigation water, the inoculum in the water must be very high and/or the infection conditions favorable (Hong et al. 2011; Tjosvold et al. 2008; Werres et al. 2007; Zappia et al. 2014). Contaminated potting media seem to be a risk for root infection, as was demonstrated for P. ramorum and Rhododendron (Parke 2007; Tjosvold et al.
2009). But leaf infection depended on the rainfall or on the type of irrigation (Parke 2007; Tjosvold et al. 2009); it increased when the plants were irrigated overhead or after heavy rainfall in spring. The risk of infection via other contaminated materials is not yet clear. Fallen leaves of the host plants increase the risk if Phytophthora species can sporulate on them as demonstrated for P. ramorum (Shishkoff 2009; Tjosvold et al. 2009; Tjosvold et al. 2008). Nevertheless, any kind of debris/residues should be removed regularly to minimize the risk of infection.

Detailed suggestions on management strategies for pests and diseases are published by Parke and Grunwald (2012). Based on the results from our studies, the following recommendations can be added for nursery surveys and management.

For surveys on Phytophthora:

(i) To check whether and which Phytophthora species are present in a nursery, plants are not the sample of choice. Puddles on pathways, runoffs, or other places with temporary or constant water are much better samples.

(ii) To check the Phytophthora situation directly on the propagation and production sections (stands in greenhouses and plastic tunnels, container stands), mixed samples from debris/residues are excellent samples.

(iii) To check whether asymptomatic plants are infected or contaminated with Phytophthora, sampling of the rootballs is better than leaves or twigs.

(iv) Samples should be taken at different seasons during the year and at different locations in the nurseries because the range of Phytophthora species and their distribution can vary with a wide range of influencing factors.

(v) A combination of baiting and subsequent study of the baits with molecular techniques can help to check large number of samples of varying quality.

For the management of Phytophthora:

(i) Pathways should be covered with materials like gravel that drain water quickly.

(ii) Puddles on pathways and stands should be filled immediately with material that drains water no matter whether they are dried or wet; that is most important if the puddle is just in front of the entrance of a greenhouse or plastic tunnel.

(iii) Temporary disinfection bath systems at the entrances of greenhouses and plastic tunnels for the periods of plant movement in and out could help to keep indoor stands in the covered sections clean.

(iv) Residues, no matter whether they are on a stand or on a pathway, should be removed regularly. They are an excellent source for inoculum.

(v) If possible, overhead irrigation should be replaced by drip irrigation.

(vi) Container stands should be reconstructed perhaps within 5 to 10 years, Phytophthora can move beneath the geomembrane.

(vii) When the geomembrane is removed for reconstruction, the layer beneath should be checked for Phytophthora contamination; if Phytophthora is detected the sublayer(s) must be replaced as well.

(viii) If substrates are stored outside, a cover could help prevent contamination via air and rain splash; nursery managers should take into consideration that the wheels of machinery (for example, for substrate transport) can carry Phytophthora from contaminated pathways to the storage area.

(ix) Runoff water that will be reused for irrigation should be disinfected. Biological-mechanical techniques like slow sand filtration systems are very effective and environmentally friendly (for examples of different techniques, see Ufer et al. 2008; Werres and Wohanka 2014). 
(x) Even if it is difficult and time consuming to disinfect the equipment, nursery managers should think of techniques to clean at least the wheels of the tractors and other machinery to prevent the spread of Phytophthora from the pathways.

(xi) Fields must be kept as clean as possible. It is extremely difficult to eliminate Phytophthora from contaminated soil. Chemicals for soil disinfection are not registered for use in nurseries in every country and are not always successful in killing Phytophthora.

\section{ACKNOWLEDGMENTS}

First of all, we would like to thank the two nursery managers and their staffs for their engagement and excellent cooperation. We also thank Marion Karolczak-Klekamp for much appreciated technical assistance in the lab. Thanks also to Everett Hansen for helpful comments. The studies were funded within the WeGa Network http://www.wega-online.org/ by the German Federal Ministry of Education and Research.

\section{LITERATURE CITED}

Balci, Y., Balci, S., MacDonald, W. L., and Gottschalk, K. W. 2008. Foliar susceptibility of eastern oak species to Phytophthora infection. Forest Pathology 38:320-331.

Bienapfl, J. C., and Balci, Y. 2014. Movement of Phytophthora spp. in Maryland's nursery trade. Plant Dis. 98:134-144.

Blaker, N. S., and MacDonald, J. D. 1981. Predisposing effects of soil moisture extremes on the susceptibility of Rhododendron to Phytophthora root and crown rot. Phytopathology 71:831-834.

Bush, E. A., Hong, C. X., and Stromberg, E. L. 2003. Fluctuations of Phytophthora and Pythium spp. in components of a recycling irrigation system. Plant Dis. 87:1500-1506.

Chastagner, G., Coats, K., and Elliott, M. 2011. Spread of Phytophthora ramorum to water, soil, and vegetation outside a nursery in Pierce County, Washington. Phytopathology 101:S32-S32.

Denman, S., Kirk, S. A., Brasier, C. M., and Webber, J. F. 2005. In vitro leaf inoculation studies as an indication of tree foliage susceptibility to Phytophthora ramorum in the UK. Plant Pathol. 54:512-521.

Duff, J. D. 1994. The incidence of Phytophthora and Pythium species in Northern Territory nurseries. Australasian Plant Pathology. 22:149-151.

Eyre, C. A., and Garbelotto, M. 2015. Detection, diversity, and population dynamics of waterborne Phytophthora ramorum populations. Phytopathology 105:57-68.

Ghimire, S. R., Richardson, P. A., Kong, P., Hu, J., Lea-Cox, J. D., Ross, D. S., Moorman, G. W., and Hong, C. 2011. Distribution and diversity of Phytophthora species in nursery irrigation reservoir adopting water recycling system during winter months. J. Phytopathol. 159:713-719.

Goss, E. M., Larsen, M., Chastagner, G. A., Givens, D. R., and Grunwald, N. J. 2009. Population genetic analysis infers migration pathways of Phytophthora ramorum in US nurseries. Plos Pathogens 5(9).

Goss, E. M., Larsen, M., Vercauteren, A., Werres, S., Heungens, K., and Grünwald, N. J. 2011. Phytophthora ramorum in Canada: Evidence for migration within North America and from Europe. Phytopathology 101:166-171.

Grunwald, N. J., Martin, F. N., Larsen, M. M., Sullivan, C. M., Press, C. M., Coffey, M. D., Hansen, E. M., and Parke, J. L. 2011. PhytophthoraID.org: A sequence-based Phytophthora identification tool. Plant Dis. 95:337-342.

Hardy, G. E., and Sivasithamparam, K. 1988. Phytophthora spp. associated with container-grown plants in nurseries in western Australia. Plant Dis. 72:435-437.

Hoitink, H. A. J., Watson, M. E., and Faber, W. R. 1986. Effect of nitrogen concentration in juvenil foliage of Rhododendron on Phytophthora dieback severity. Plant Dis. 70:292-294.

Hoitink, H. A. J., and Powell, C. C., Jr. 1990. Fighting Phytophthora - a guide to combating Phytophthora root rot and dieback in ericaceous crops. Am. Nurseryman 171(10):67-73.

Hong, C., Richardson, P. A., and Kong, P. 2008. Pathogenicity to ornamental plants of some existing species and new taxa of Phytophthora from irrigation water. Plant Dis. 92:1201-1207.

Hong, C., Richardson, P., Ghimire, S., Kong, P., Hu, J., Moorman, G., LeaCox, J., and Ross, D. 2011. Diversity of Phytophthora species identified in a nursery irrigation runoff water containment basin of eastern Virginia. Phytopathology 101:S74-S74.
Hulvey, J., Gobena, D., Finley, L., and Lamour, K. 2010. Co-occurrence and genotypic distribution of Phytophthora species recovered from watersheds and plant nurseries of eastern Tennessee. Mycologia 102:1127-1133.

Hummel, R. L., Elliott, M., Chastagner, G., Riley, R. E., Riley, K., and DeBauw, A. 2013. Nitrogen fertility influences growth and susceptibility of Rhododendrons to Phytophthora ramorum. Hortscience 48:601-607.

Linderman, R. G., and Davis, E. A. 2006. Survival of Phytophthora ramorum compared to other species of Phytophthora in potting media components, compost, and soil. HortTechnology 16:502-507.

Loyd, A., Benson, D. M., and Ivors, K. 2011. Identifying Phytophthora species isolated from nursery irrigation water throughout North Carolina. Phytopathology 101:S110-S110.

Loyd, A. L., Benson, D. M., and Ivors, K. L. 2014. Phytophthora populations in nursery irrigation water in relationship to pathogenicity and infection frequency of Rhododendron and Pieris. Plant Dis. 98:1213-1220.

Parke, J. L., Linderman, R. G., Osterbauer, N. K., and Griesbach, J. A. 2004. Detection of Phytophthora ramorum blight in Oregon nurseries and completion of Koch's postulates on Pieris, Rhododendron, Viburnum, and Camellia. Plant Dis. 88:87-87.

Parke, J. L. 2007. Root and stem infection of rhododendron from potting medium infested with Phytophthora ramorum. Plant Dis. 91:1265-1270.

Parke, J. L., and Grunwald, N. J. 2012. A systems approach for management of pests and pathogens of nursery crops. Plant Dis. 96:1236-1244.

Prospero, S., Vercauteren, A., Heungens, K., Belbahri, L., and Rigling, D. 2013. Phytophthora diversity and the population structure of Phytophthora ramorum in Swiss ornamental nurseries. Plant Path. 62:1063-1071.

Roubtsova, T. V., and Bostock, R. M. 2009. Episodic abiotic stress as a potential contributing factor to onset and severity of disease caused by Phytophthora ramorum in Rhododendron and Viburnum. Plant Dis. 93:912-918.

Rytkonen, A., Lilja, A., Vercauteren, A., Sirkia, S., Parikka, P., Soukainen, M., and Hantula, J. 2012. Identity and potential pathogenicity of Phytophthora species found on symptomatic Rhododendron plants in a Finnish nursery. Can. J. Plant Pathol. 34:255-267.

Rytkonen, A., Lilja, A., Werres, S., Sirkia, S., and Hantula, J. 2013. Infectivity, survival and pathology of Finnish strains of Phytophthora plurivora and Ph. pini in Norway spruce. Scand. J. For. Res. 28(4):307-318.

Schena, L., Duncan, J. M., and Cooke, D. E. L. 2008. Development and application of a PCR-based 'molecular tool box' for the identification of Phytophthora species damaging forests and natural ecosystems. Plant Pathol. 57:64-75.

Schlenzig, A., Campbell, R., and Chard, J. 2015. Phytophthora species infecting hardy ornamentals in nurseries and the managed environment in Scotland. J. Phytopathol. 163:686-689.

Schoebel, C. N., Stewart, J., Gruenwald, N. J., Rigling, D., and Prospero, S. 2014. Population history and pathways of spread of the plant pathogen Phytophthora plurivora. Plos One. 9(1):11.

Shishkoff, N. 2007. Persistence of Phytophthora ramorum in soil mix and roots of nursery ornamentals. Plant Dis. 91:1245-1249.

Shishkoff, N. 2009. Propagule production by Phytophthora ramorum on lilac (Syringa vulgaris) leaf tissue left on the surface of potting mix in nursery pots. Plant Dis. 93:475-480.

Shishkoff, N. 2011. Risk analysis of native and ornamental plants for root infection and inoculum production from roots by Phytophthora ramorum. Phytopathology 101:S166-S166.

Themann, K., and Werres, S. 2000. Experience with different diagnostic techniques to detect Phytophthora species in water. 4th IUFRO Working Party 7.03.04, Diseases and Insects in Forest Nurseries. The Finnish Forest Research Institute, Helsinki, Finland.

Themann, K., Werres, S., Diener, H. A., and Luttmann, R. 2002a. Comparison of different methods to detect Phytophthora spp. in recycling water from nurseries. J. Plant Pathol. 84:41-51.

Themann, K., Werres, S., Luttmann, R., and Diener, H. A. 2002b. Observations of Phytophthora spp. in water recirculation systems in commercial hardy ornamental nursery stock. Eur. J. Plant Pathol. 108:337-343.

Tjosvold, S. A., Chambers, D. L., Koike, S. T., and Mori, S. R. 2008. Disease on nursery stock as affected by environmental factors and seasonal inoculum levels of Phytophthora ramorum in stream water used for irrigation. Plant Dis. 92:1566-1573.

Tjosvold, S. A., Chambers, D. L., Fichtner, E. J., Koike, S. T., and Mori, S. R. 2009. Disease risk of potting media infested with Phytophthora ramorum under nursery conditions. Plant Dis. 93:371-376. 
Ufer, T., Werres, S. K., Posner, M., and Wessels, H.-P. 2008. Filtration to eliminate Phytophthora spp. from recirculating water systems in commercial nurseries. Plant Health Prog. doi:10.1094/PHP-2008-031401-RS.

Van Poucke, K., Vercauteren, A., Maes, M., Werres, S., and Heungens, K. 2012. Genotypic Diversity of European Phytophthora ramorum Isolates Based on SSR Analysis. 5th Sudden Oak Death Science Symposium. USDA Pacific Southwest Research Station, Petaluma, CA.

Vercauteren, A., Riedel, M., Maes, M., Werres, S., and Heungens, K. 2013. Survival of Phytophthora ramorum in Rhododendron root balls and in rootless substrates. Plant Pathol. 62:166-176.

Warfield, C. Y., Hwang, J., and Benson, D. M. 2008. Phytophthora blight and dieback in North Carolina nurseries during a 2003 survey. Plant Dis. 92:474-481.

Webber, J. F., Mullett, M., and Braisier, C. M. 2010. Dieback and mortality of plantation Japanese larch (Larix kaempferi) associated with infection by Phytophthora ramorum. New Dis. Rep. 22:19.

Werres, S., Marwitz, R., Veld, W. A. M. I., De Cock, A. W. A. M., Bonants, P. J. M., De Weerdt, M., Themann, K., Ilieva, E., and Baayen, R. P. 2001. Phytophthora ramorum sp nov., a new pathogen on Rhododendron and Viburnum. Mycol. Res. 105:1166-1175.
Werres, S., Wagner, S., Brand, T., Kaminski, K., and Seipp, D. 2007. Survival of Phytophthora ramorum in recirculating irrigation water and subsequent infection of Rhododendron and Viburnum. Plant Dis. 91:1034-1044.

Werres, S., and Wohanka, W. 2014. Filtration and constructed wetlands for irrigation water treatment. Pages 209-233 in: Biology, Detection and Management of Plant Pathogens in Irrigation Water. H. Chuanxue, G. Moorman, W. Wohanka, and C. Büttner, eds. The American Phytopathological Society, St. Paul, MN.

White, T. J., Bruns, T., Lee, S., and Taylor, J. W. 1990. Amplification and direct sequencing of fungal ribosomal RNA genes for phylogenetics. Pages 315-322 in: PCR Protocols: A Guide to Methods and Applications. M. A. Innis, D. H. Gelfand, J. J. Sninsky, and T. J. White, eds. Academic Press, Inc., New York.

Widmer, T. L., Shishkoff, N., and Dodge, S. 2010. Root susceptibility and inoculum production from roots of eastern oak species to Phytophthora ramorum. Phytopathology. 100:S136-S136.

Zappia, R. E., Huberli, D., Hardy, G., and Bayliss, K. L. 2014. Fungi and oomycetes in open irrigation systems: knowledge gaps and biosecurity implications. Plant Pathol. 63:961-972. 